\title{
Potret Sikap Mahasiswa dalam Penggunaan Literasi Digital
}

\author{
Hendra Nelva Saputra ${ }^{1}$, Salim $^{2}$ \\ ${ }^{1}$ Pendidikan Teknologi Informasi, Universitas Muhammadiyah Kendari \\ ${ }^{* 2}$ Pendidikan Matematika, Universitas Halu Oleo \\ Email: $\underline{\text { Hendratep2015@gmail.com }}$,
}

\begin{abstract}
Abstrak
Tujuan penelitian ini adalah untuk mengetahui potret penggunaan literasi digital mahasiswa yang ditinjau dari kepemilikan media sosial, penggunaan perangkat teknologi, dan sikap mahasiswa dalam penggunaan perangkat teknologi. Penelitian ini menggunakan metode deskriptif kuantitatif. Data dikumpulkan dengan pemberian kuisioner yang disertai alasan pemilihan jawaban yang dipilih. Data pada penelitian ini dianalisis secara deskriptif yang disajikan dalam bentuk diagram batang untuk menggambarkan potret pengunaan literasi digital pada mahasiswa program studi Pendidikan Teknologi Informasi Universitas Muhammadiyah Kendari. Hasil penelitian menunjukkan bahwa whatsapp merupakan media sosial yang paling digunakan mahasiswa dengan persentase sebesar 97,3\%. Ditinjau dari penggunaan perangkat teknologi, mahasiswa menggunakan perangkat teknologi untuk keperluan pembelajaran yang dapat dimanfaatkan mahasiswa sebagai media pembelajaran mandiri, alat bantu pembelajaran, dan sumber belajar. Tinjauan sikap mahasiswa dalam penggunaan perangkat teknologi menunjukkan bahwa sebagian besar mahasiswa telah memiliki sikap yang positif dalam menggunakan perangkat teknologi. Mahasiswa telah memiliki sikap menghargai perbedaan pendapat, menghargai privasi orang lain, memperhatikan resiko hokum dalam berkomunikasi, memiliki kemauan yang kuat, dan membaca konten secara cermat.
\end{abstract}

Kata-kata kunci: literasi digital, sikap mahasiswa

\section{Portrait of Student Attitudes in the Use of Digital Literacy}

\author{
Hendra Nelva Saputra ${ }^{1}$, Salim$^{2}$ \\ ${ }^{1}$ Departement of Information Technology Education, Universitas Muhammadiyah Kendari \\ ${ }^{*}$ Departement of Mathematics Education, Universitas Halu Oleo \\ Email: Hendratep2015@gmail.com
}

\begin{abstract}
The purpose of this research is to know the use of digital literacy for students that are reviewed from social media ownership, technological use, and student attitudes in the use of technological devices. This research uses quantitative descriptive methods. Data is collected with a questionnaire that is accompanied by the reason for selecting the chosen answer. The Data on this study was analyzed descriptively presented in the form of a bar diagram to describe the use of digital literacy in the University Information Technology Education Program of Muhammadiyah Kendari. The results showed that WhatsApp was the most used social media student with a percentage of $97.3 \%$. Reviewed from the use of technological devices, students use technology devices for learning purposes that students can utilize as a self-learning media, learning aids, and learning resources. A review of student attitudes in the use of technological devices shows that most students have had a positive attitude in using technological devices. Students have an attitude to respect disagreements, respect the privacy of others, pay attention to the risks involved in communicating, have a strong will, and read the content carefully.
\end{abstract}

Keywords: digital literacy, student attitude 


\section{PENDAHULUAN}

Kecakapan pembelajaran abad ke 21 memprasyaratkan budaya literasi sebagai komponen yang harus dikembangkan bersama melalui pendidikan terintegrasi mulai dari keluarga, lembaga pendidikan, dan masyarakat. Literasi merupakan kemampuan individu dalam menggunakan potensi dan keterampilan dalam mengolah dan memahami informasi saat membaca, menulis, berhitung, dan memberikan solusi alternatif terhadap masalah dalam kehidupan seharihari. Salah satu bentuk budaya literasi adalah literasi digital.

Hague dan Payton (2010) memaparkan literasi digital merupakan keterampilan individu dalam mengaplikasikan keterampilan fungsional pada perangkat digital sehingga dapat menemukan, memilih dan memilah informasi, berpikir kritis, berkreativitas, berkolaborasi, dan berkomunikasi secara efektif. Pendapat lain dikemukakan oleh Febliza dan Oktariani (2020) yang menjelaskan literasi digital merupakan kecakapan hidup (life skills) yang tidak hanya melibatkan kemampuan menggunakan perangkat teknologi, informasi, dan komunikasi, tetapi juga kemampuan bersosialisasi, kemampuan dalam pembelajaran, dan memiliki sikap, berpikir kritis, kreatif, serta inspiratif sebagai kompetensi digital.

Zhang \& Zhu (2016) menjelaskan keterampilan masyarakat dalam memahami karakteristik digital, fitur teknologi digital, dan efek digital merupakan bagian dari keterampilan literasi digital yang dibutuhkan masyarakat pada abad ke 21. Kurnianingsih, Rosini, dan Ismayati (2017) mengungkapkan karakteristik literasi digital tidak hanya mengacu pada keterampilan operasi dan menggunakan berbagai perangkat teknologi informasi dan komunikasi, tetapi juga untuk proses membaca dan memahami sajian isi perangkat teknologi serta proses menciptakan dan menulis menjadi sebuah pengetahuan baru. Informasi dapat menjadi pengetahuan baru yang menurut Hakim (2017) bahwa informasi dapat dengan mudah diperolah dan disebarluaskan dengan laju kepada pengguna yang mengaksesnya.

Literasi digital menjadi bagian penting dalam pengembangan proses pembelajaran di perguruan tinggi. Temuan dalam penelitian Kurnia, Santi, dan Astuti (2017) menunjukkan perguruan tinggi merupakan pelaku utama dalam gerakan literasi digital sebesar 56,14\%. Keminfo bekerja sama dengan UNICEF juga memberikan informasi bahwa sekitar 79,5\% anak dan remaja usia 10-19 tahun di Indonesia merupakan pengguna internet dan media digital. Usia $17-$ 19 tahun yang masuk rentang dalam temuan tersebut menunjukkan usia mahasiswa dalam perguruan tinggi.

Penjabaran di atas didukung oleh temuan dalam penelitian Shopova (2014) menunjukkan bahwa sebagian besar mahasiswa yang masuk ke universitas 
memiliki keterampilan yang baik dalam menggunakan jejaring sosial, e-mail atau skype, surfing internet sebagai komunitas di dunia maya, namun pengetahuan dan kompetensi mahasiswa mengenai penggunaan teknologi untuk proses pembelajaran masih tergolong rendah.

Program Studi Pendidikan Teknologi Informasi sebagai bagian dari Universitas Muhammadiyah Kendari merupakan program studi yang masih tergolong muda. Saat ini program studi pendidikan teknologi informasi baru memiliki 2 angkatan dengan jumlah mahasiswa 240 orang. Meski demikian, selaku program studi berbasis IT, maka seluruh civitas akademik terus melakukan pembaharuan sesuai dengan perkembangan zaman dan tuntutan pembelajaran abad ke 21 .

Hasil observasi awal menunjukkan bahwa rata-rata mahasiswa telah memiliki perangkat teknologi seperti handphone, laptop/notebook, hard disk, dan flash disk. Temuan lainnya menunjukkan rata-rata mahasiswa telah memiliki akses wifi pada lingkungan tempat tinggal yang dapat diakses setiap saat. Hal ini membuktikan kesiapan perangkat teknologi mahasiswa telah memadai untuk melakukan berbagai aktivitas di dunia maya. Meski demikian, kesiapan perangkat teknologi mahasiswa harus sejalan dengan kemampuan mahasiswa dalam menciptakan informasi yang mudah dipahami oleh khalayak ramai, sebab kemampuan literasi digital tidak hanya sekadar menggunakan, mencari, dan menyebarkan informasi, akan tetapi juga membuat informasi dengan menggunakan media digital. Menurut Willems, Farley, \& Campbell (2019) setiap individu masyarakat memiliki peran aktif untuk ikut berpartisipasi pada era digital saat untuk menunjang proses pembelajaran pada pendidikan tinggi.

Literasi digital sangat dibutuhkan oleh para pendidik sebagai relevansi kebutuhan pelajar dengan trend penggunaan digital dalam kelas pembelajaran (Kurniawati, Maolida, \& Anjaniputra, 2018). Menurut Juliana \& Baroroh (2016), adanya trend literasi digital menjadi kebutuhan akademik pada perguruan tinggi, mengingat mahasiswa sekarang ini menjadi searching google sebagai sumber refensi belajar.

Rahmah (2015) mengungkapkan literasi digital perlu didukung melalui sistem pembelajaran terintegrasi dengan menajemen pengetahuan. Menurut Harjono (2019), pengguna literasi digital sangat memungkinkan untuk mengusai semua dimensi pengalaman belajar yaitu sikap, pengetahuan dan keterampilan. Sparks, Katz, \& Beile (2016) yang mengemukakan bahwa informasi literasi digital membantu keberhasilan akademik mahasiswa pada lembaga pendidikan tinggi.

Berdasarkan uraian tersebut, maka tujuan yang ingin dicapai dalam penelitian ini adalah untuk mengetahui potret penggunaan literasi digital dan kemampuan mahasiswa dalam menciptakan informasi menggunakan media digital. 


\section{METODE}

Penelitian ini merupakan penelitian deskriptif kuantitatif yang bertujuan untuk mengetahui potret sikap mahasiswa dalam penggunaan literasi digital.

Penelitian ini dilaksanakan di Fakultas Keguruan dan Ilmu Pendidikan Universitas Muhammadiyah Kendari pada mahasiswa program studi Pendidikan Teknologi Informasi untuk semester genap tahun akademik 2019/2020.

Populasi dalam penelitian ini adalah seluruh mahasiswa Program Studi Pendidikan Teknologi Informasi Universitas Muhammadiyah Kendari yang berjumlah 240. Sementara sampel penelitian diambil dengan teknik purposive sampling yaitu dari dua angkatan yang ada masing-masing diambil 30 orang per angkatan sehingga jumlah sampel sebanyak 60 mahasiswa.

Variabel yang diukur dalam penelitian ini yaitu literasi digital yang digunakan oleh mahasiswa program studi Pendidikan Teknologi Informasi Universitas Muhammadiyah Kendari. Aspek literasi digital yang diamati adalah (1) kepemilikan media sosial, (2) penggunaan perangkat teknologi, dan (3) sikap mahasiswa dalam penggunaan perangkat teknologi.

Data dikumpulkan dengan pemberian kuisioner yang disertai alasan pemilihan jawaban yang dipilih. Data pada penelitian ini dianalisis secara deskriptif yang disajikan dalam bentuk diagram batang untuk menggambarkan potret pengunaan literasi digital pada mahasiswa program studi Pendidikan Teknologi Informasi Universitas Muhammadiyah Kendari. 


\section{HASIL DAN PEMBAHASAN}

Deskripsi penggunaan literasi digital pada mahasiswa Pendidikan Teknologi Informasi Universitas Muhammadiyah Kendari dikategorikan dalam 3 kategori yaitu: (1) kepemilikan media sosial, (2) penggunaan perangkat teknologi, dan (3) sikap mahasiswa dalam penggunaan perangkat teknologi.

\section{Kepemilikan Media Sosial}

Media sosial yang dimaksud dalam penelitian ini meliputi website/blog, facebook, whatsapp, Instagram, twitter, dan line. Adapun tanggapan mahasiswa terhadap kepemilikan media sosial tersebut dapat dilihat pada gambar 1 berikut.

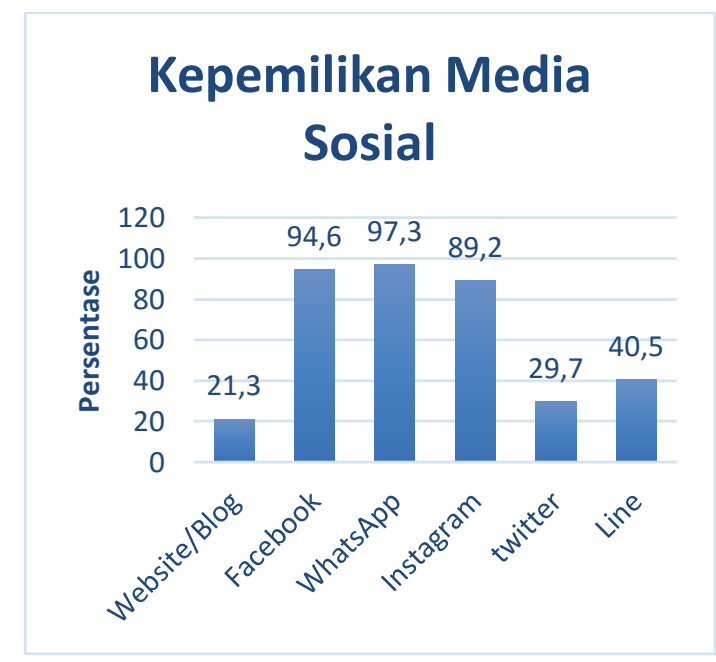

Gambar 1. Persentase Kepemilikan Media Sosial Mahasiswa

Berdasarkan persentase kepemilikan media sosial mahasiswa, terlihat bahwa dominan mahasiswa telah memiliki media sosial whatsapp, facebook, dan instagram dengan persentase masing-masing secara berturut-turut adalah 97,3\%, 94,6\%, dan $89,2 \%$. Hal ini menunjukkan bahwa whatsapp menjadi aplikasi media sosial tertinggi yang dimiliki oleh mahasiswa. Sedangkan kepemilikan media sosial terendah ada pada website/blog dengan persentase hanya 21,3\%. Hasil ini juga diungkapkan oleh Setyaningsih, et al. (2019) bahwa kebanyakan mahasiswa menggunakan internet untuk kegiatan updating dan sharing status pada media sosialnya..

Whatsapp menjadi aplikasi media sosial tertinggi yang digunakan oleh mahasiswa, sebab whatsapp telah dilengkapi dengan beragam fitur yang mudah dipahami sehingga memudahkan mahasiswa untuk menggunakannya. Fitur-fitur yang terdapat dalam Whatsapp yaitu Gallery, Contact, Camera, Audio, Maps, dan Document. Apabila pengguna hendak menambahkan foto maka dapat menggunakan fitur Gallery, Contact untuk menyisipkan kontak, Camera untuk mengambil gambar, Audio untuk mengirim pesan suara, Maps untuk mengirimkan berbagai koordinat peta, dan Document untuk menyisipkan file berupa dokumen. Kelengkapan fitur ini sangat menunjang mahasiswa dalam proses pembelajaran. Penjelasan ini senada dengan Dearstyne (2011) yang menyatakan bahwa Whatsapp merupakan salah satu teknologi yang sangat potensial untuk digunakan sebagai media pembelajaran. Tafonao (2018) memaparkan media pembelajaran merupakan segala sesuatu yang dapat digunakan untuk menyalurkan pesan pengirim kepada penerima, sehingga dapat merangsang 
pikiran, perasaan, perhatian, dan minat peserta didik untuk belajar. Hasil penelitian Jumiatmoko (2016) menunjukkan Whatsapp memberikan kesempatan bagi civitas akademik untuk menggelar berbagai kelas virtual berbasis online dan fitur multimedia tanpa batasan ruang dan waktu.

\section{Penggunaan Perangkat Teknologi}

Penggunaan perangkat teknologi berfokus pada pemanfaatan perangkat teknologi yang dimiliki oleh mahasiswa. Berdasarkan hasil jawaban mahasiswa, diperoleh data bahwa mahasiswa menggunakan perangkat teknologi yang dimilikinya untuk hal-hal berikut: (1) menggunakan perangkat teknologi untuk mendownload materi/tugas perkuliahan, (2) melakukan browsing internet untuk mencari referensi/sumber belajar, (3) mengupdate informasi terkini melalui kunjungan website tertentu sebagai penunjang kegiatan perkuliahan, (4) menjelajah internet untuk mendownload materi terkait tugas perkuliahan, (5) memperoleh bahan materi/tugas melalui grup-grup media sosial, (6) menggunakan fitur pada handphone dan jejaring sosial untuk berkomunikasi dengan teman lainnya, (7) memanfaatkan fitur jejaring sosial untuk berbagi konten perkuliahan, dan (8) mahir membuat slide presentasi dalam bentuk power point.
Penjabaran di atas membuktikan bahwa mahasiswa menggunakan perangkat teknologi untuk keperluan pembelajaran. Penggunaan perangkat teknologi untuk keperluan pembelajaran dapat memberikan manfaat sebagai media pembelajaran mandiri, alat bantu pembelajaran, dan sebagai sumber belajar. Idris (2015) dalam penelitiannya menyimpulkan penggunaan teknologi informasi dan komunikasi secara terus menerus dalam pembelajaran akan mampu memberikan motivasi belajar terhadap peserta didik sehingga mereka akan terbiasa belajar mandiri dalam mencari informasi-informasi yang berkaitan dengan materi pembelajarannya.

Hasil jawaban responden juga menunjukkan bahwa mahasiswa belum menggunakan perangkat teknologi untuk halhal berikut: (1) mengunggah/mengupload materi pada website/blog pribadi, (2) menggunakan layanan email untuk berkomunikasi dengan teman lainnya, (3) menulis artikel pada pada website/blog sendiri sebagai sumber informasi/referensi, (4) menggunakan aplikasi dalam membuat objek dua dan tiga dimensi, (5) membuat vlogging (video blog) di channel youtoube dan aplikasi video lainnya, dan (6) menggunakan jejaring sosial untuk membangun koneksi di tingkat lokal, regional, dan nasional untuk mendukung tugas akademik. 


\section{Sikap Mahasiswa dalam Penggunaan Perangkat Teknologi}

Hasil jawaban responden terhadap sikapnya dalam penggunaan perangkat teknologi dapat dilihat pada gambar 2 berikut:

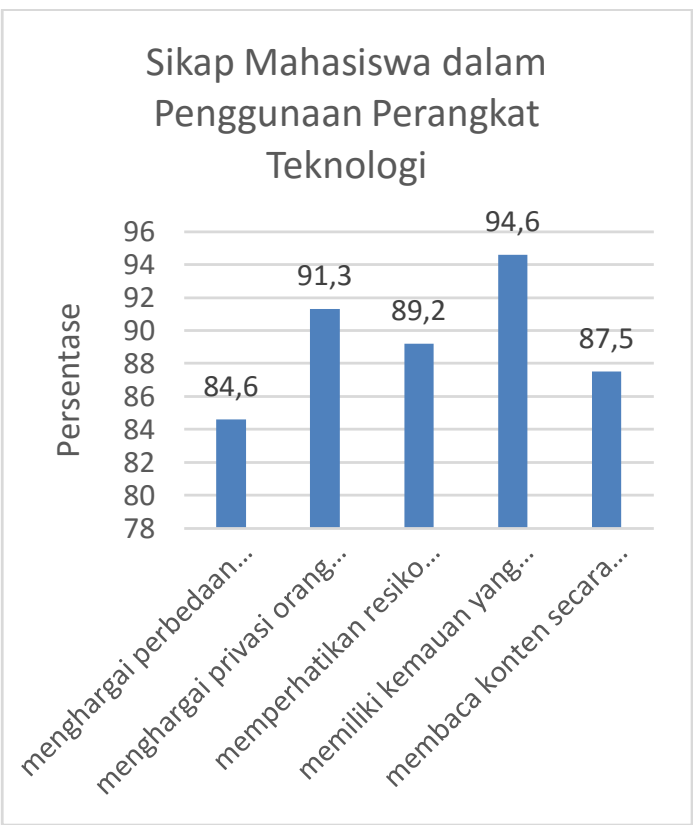

Gambar 2. Sikap Mahasiswa dalam Penggunaan Perangkat Teknologi

Merujuk pada gambar 2 di atas dapat digambarkan bahwa mahasiswa saling menghargai perbedaan pendapat saat berdiskusi melalui forum online/jejaring sosial dengan persentase $84,6 \%$, saling menghargai privasi antara satu sama lain saat berkomunikasi melalui forum online dengan persentase $91,3 \%$, memperhatikan resiko hukum dalam berkomunikasi melalui forum online, memiliki kemauan yang kuat dalam menggunakan perangkat/aplikasi sebagai penunjang untuk membantu percepatan tugas perkuliahan dengan persentase $94,6 \%$, dan membaca konten secara cermat dengan persentase $87,5 \%$. Hal ini mengindikasikan bahwa sebagian besar mahasiswa memiliki sikap yang positif dalam menggunakan perangkat teknologi. Hasil ini sejalan dengan ungkapan oleh Akbar \& Anggaraeni (2017) bahwa teknologi digital sekarang sangat membantu mahasiswa untuk memiliki sumber belajar sehingga studi akademiknya dapat ditempuh dengan baik.

\section{SIMPULAN DAN SARAN}

Potret penggunaan literasi digital mahasiswa Pendidikan Teknologi Informasi Universitas Muhammadiyah Kendari dapat ditinjau dari 3 aspek yaitu kepemilikan media sosial, penggunaan perangkat teknologi, dan sikap mahasiswa dalam penggunaan perangkat teknologi. Ditinjau dari kepemilikan media sosial, whatsapp menjadi aplikasi tertinggi yang digunakan oleh mahasiswa dengan persentase 97,3\%. Ditinjau dari penggunaan perangkat teknologi, mahasiswa menggunakan perangkat teknologi untuk keperluan pembelajaran yang dapat dimanfaatkan mahasiswa sebagai media pembelajaran mandiri, alat bantu pembelajaran, dan sumber belajar.

Tinjauan sikap mahasiswa dalam penggunaan perangkat teknologi menunjukkan bahwa sebagian besar mahasiswa telah memiliki sikap yang positif dalam menggunakan perangkat teknologi. Mahasiswa telah memiliki sikap menghargai perbedaan pendapat, menghargai privasi 
orang lain, memperhatikan resiko hokum dalam berkomunikasi, memiliki kemauan yang kuat, dan membaca konten secara cermat.

Peneliti memberikan rekomendasi kepada peneliti lain untuk melakukan penelitian berupa analisis pembelajaran online yang dilakukan mahasiswa berdasarkan hasil penelitian ini.

\section{DAFTAR REFERENSI}

Akbar, M. F., \& Anggaraeni, F. D. (2017). Teknologi dalam Pendidikan: Literasi Digital Dan Self-Directed Learning pada Mahasiswa Skripsi. Jurnal Indigenous, 2(1), 28-38.

https://doi.org/10.23917/indigenous.v1i1.44 58

Dearstyne, B.,W. (2011). Smart phones: e new information revolution?.e Information Management Journal, vol. 39, hlm. 38-44

Febliza, A. \& Oktariani. (2020). Pengembangan Instrumen Literasi Digital Sekolah Siswa dan Guru. Jurnal Pendidikan Kimia Universitas Riau, Vol. 5, No. 1, 1-10

Hague, C., \& Payton, S. (2010). Digital Literacy Across the Curriculum: a Futurelab Handbook. United Kingdom.

Hakim, H. A. B. (2017). Aplikasi Teknologi Informasi Di Perpustakaan Sekolah: Dari Otomasi Sampai Literasi Informasi. Yogyakarta: Lembaga Ladang Kata.

Harjono, H. S. (2019). Literasi Digital: Prospek dan Implikasinya dalam Pembelajaran Bahasa. Pena : Jurnal Pendidikan Bahasa Dan Sastra, 8(1), 1-7. https://doi.org/10.22437/pena.v8i1.6706

Idris. (2015). Efektivitas Penggunaan Teknologi Informasi dan Komunikasi dalam Pembelajaran Pendidikan Agama Islam. POTENSIA: Jurnal Kependidikan Islam, Vol. 1, No. 2, 175-190

Juliana, K., \& Baroroh, S. (2016). Literasi Media Digital Mahasiswa Universitas Muhammadiyah Bengkulu. Jurnal Komunikator, 8(2), 51-66.
Jumiatmoko. (2016). Whatsapp Messenger dalam Tinjauan Manfaat dan Adab. Wahana Akademika, Vol. 3, No. 1, 51-66

Kurnianingsih, I., Rosini. \& Ismayati, N. (2017). Upaya Peningkatan Kemampuan Literasi Digital bagi Tenaga Perpustakaan Sekolah dan Guru di Wilayah Jakarta Pusat Melalui Pelatihan Literasi Informasi. Jurnal Pengabdian kepada Masyarakat, Vol. 3, No. 1, 61-76

Kurniawati, N., Maolida, E. H \& Anjaniputra, A. G. (2018). The praxis of digital literacy in the EFL classroom: Digitalimmigrant vs digital-native teacher. Indonesian Journal Of Applied Linguistics, 8 (1), 28-37. https://doi.org/10.17509/ijal.v8i1.11459

Rahmah, A. (2015). Digital Literacy Learning System for Indonesian Citizen. Procedia Computer Science, 72, 94-101. https://doi.org/10.1016/j.procs.2015.12.109.

Sparks, J. R., Katz, I. R., \& Beile, P. M. (2016). Assessing Digital Information Literacy in Higher Education: A Review of Existing Frameworks and Assessments With Recommendations for Next Generation Assessment. ETS Research Report Series, 2016(2), 1-33. http://doi.org/10.1002/ets2.12118

Setyaningsih, R., Abdullah, Prihantoro, E., \& Hustinawaty. (2019). Model Penguatan Literasi Digital Melalui Pemanfaatan ELearning. Jurnal Komunikasi ASPIKOM, 3(6), 1200-1214. http://dx.doi.org/10.24329/aspikom.v3i6.33 3

Tafonao, Talizaro. (2018). Peranan Media Pembelajaran dalam Meningkatkan Minat Belajar Mahasiswa. Jurnal Komunikasi Pendidikan, Vol. 2, No. 2, 103-114. https://doi.org/10.32585/jkp.v2i2.113

Willems, J., Farley, H., \& Campbell, C. (2019). The Increasing Significance Of Digital Equity In Higher Education. Australasian Journal of Educational Technology, 35(6), 1-8. https://doi.org/10.14742/ajet.5996.

Zhang, H. \& Zhu, C. (2016). A study of digital media literacy of the 5 th and 6th grade primary students in Beijing. Asia-Pacific Education Researcher, 25(4), 579-592. 